For them feminism seems, well, a little old-fashioned. Or else something which patronizes them by assuming, from the start, that they naturally need it, that feminism offers something they haven't already got or achieved.

All That Is Solid urges us to consider not only the new forms of misery which capitalism, in its decline, creates, but also the new forms of culture and politics which direct experience of these conditions brings into being. And for the Women's Movement this might mean new and different, even unrecognizable, forms of feminism appearing across a range of social locations.

\section{Angela McRobbie}
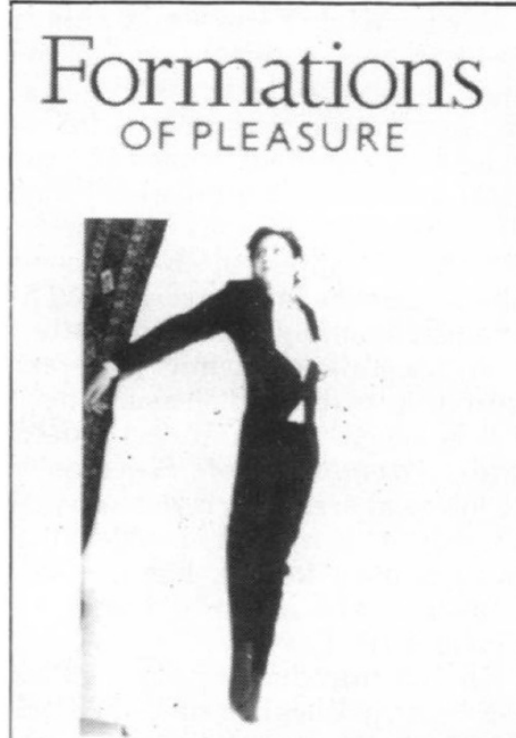

Formations of Pleasure Editors, Tony Bennett et al Routledge Kegan Paul 1983 180pp $\mathrm{Pb}$ £5.95. ISBN 0-7100-9359-4

Formations of Pleasure is the first issue of a new twice yearly journal 'of feminist and socialist cultural theory, history and debate'. The stated aims of the editorial collective are 'to explore the social manage-

\section{References}

ANDERSON, Perry (1984) 'Modernity and Revolution' New Left Review No. 144 March-April.

BENJAMIN, Walter (1973) Charles Baudelaire: A lyric poet in the era of high capitalism London: New Left Books.

BERMAN, Marshall (1984) 'The Signs in the Street' New Left Review No. 144 March-April.

GUY, Rosa (1984) A Measure of Time London: Virago.

ROWBOTHAM, Sheila (1973) Woman's Consciousness, Man's World Harmondsworth: Penguin.

WALKER, Alice (1982) The Colour Purple London: The Women's Press.

ment of what we enjoy and the possibilities for creating new forms of pleasure to displace existing ones'.

Within much recent feminist cultural theory, thequestion of pleasure has become pivotal both for understanding of the ways in which sexed subjectivity is constructed within cultural practices and discourses, and in our attempts to intervene and subvert these processes. Given the centrality of questions of pleasure for much contemporary feminist cultural theory, it is surprising that only four of the fourteen contributions to this collection are from feminists.

Cora Kaplan's 'Wild Nights: Pleasure / Sexuality / Feminism' addresses many difficult issues raised for feminist theory by the question of pleasure. In her essay Kaplan argues that an examination of the history of feminist discourses reveals a crucial absence. For while the theme of female sexuality has recurred within these discourses with an apparent inevitability, the same cannot be said for the theme of sexual pleasure. Kaplan draws out the similarities between Mary Wollstonecraft's 'Vindication of the Rights of Women' and Adrienne 
Rich's 'Compulsory Heterosexuality and Lesbian Existence', arguing that like Wollstonecraft, if more tentatively, Rich also poses a rereformed libidinal economy for women as the precondition for the successful liberation of women. Kaplan goes on to argue that though there was a brief moment in the early 1970 s when a space was opened up within feminism for the discussion of female sexual pleasure, this space was very quickly closed again, returning us to a situation 'where female sexuality is indisputably centre-stage in feminist debates, but pleasure is too rarely its subject' and where 'Eros rampant is more likely to conjure up a snuff movie than a multiple orgasm' (p34). Kaplan concludes her essay by suggesting that feminists must 'work to understand why it was that this moment within recent feminism was so short-lived'. This is undoubtedly an important question for feminism but Kaplan's article points towards another absence within feminism, the absence of an adequate theory to explain the relations between the construction of sexed subjectivity, of discourse and of power relations. While it is tempting to posit pleasure as the 'missing link' between subjectivity, power and cultural practices, we still need a theory to explain how all the links fit together.

In 'Feminist Film Practice and Pleasure' DeeDee Glass, Laura Mulvey, Griselda Pollock and Judith Williamson discuss their experiences of attempting to bridge the gap between feminist film theory and practice. For all of them questions of pleasure, both of consumption and of production, prove the most crucial and most contentious. Their discussion ranges over issues familiar to most students of feminist film theory: should feminist film strategy aim to destroy the visual pleasures of dominant Hollywoodstyle practice? Or is such avantgardism inherently élitist? Are feminist filmmakers being co-opted into the dominant culture if they demand recognition as 'individuals' and artists in their own right'? Have the avant-gardist feminist film strategies of followers of Chantal Akerman or Laura Mulvey already been incorporated becoming mere signs of cinematic stylishness or fashion? Can narcissistic or voyeuristic identification with the screen image ever be politically progressive? While the wide-ranging discussion raises little that has not already been raised within feminist film culture, this contribution does provide a summary of the major issues facing feminist film theory and practice today and should prove useful for students and for those wishing to acquaint themselves with the main issues.

While these contributions to this issue of Formations-and the photoessay by Marie Yates-may appear to be of most direct relevance and significance for readers of Feminist Review, the other ten articles in this collection represent what can only be described as a veritable explosion of writing on pleasure and desire which has appeared in the bookshops over the last three years. The explosion surely needs investigation for this academic gold-rush into the realm of pleasure itself needs some explanation. Indeed, with Formations of Pleasure, a theoretical area which was recently thought of as in need of exploration is beginning to look like an overexploited and already somewhat depleted field.

In his introductory essay 'Pleasure: a political issue', Frederic Jameson posits allegory as 'the only proper political use of pleasure' (p13) not a suggestion likely to set many feminist hearts aflame. Yet many of the questions raised in his essay have yet to be fully or adequately addressed within feminist theory. In order to argue his case, Jameson has produced a considered historical analysis of the concept of pleasure as it has appeared within a range of political and theoretical discourses. While this trajectory 
from Marcuse to Barthes and Mulvey, with sideways glances at the Frankfurt school, Burke and Nietzsche, does read tortuously at times, in describing it Jameson points towards a cluster of ambiguities implicit within much contemporary theorizations of pleasure. The most productive of these,to my mind, being his attempt to 'trace a politics and historicity of jouissance'. Jameson asks, for example, is not the aesthetics of ecstasy, Barthesian jouissance, a properly 1960 s experience... or is the experience so new and without historical antecedents or analogies whatsoever?' Jameson argues that our contemporary concern with the Barthesian aesthetic 'the sudden stab of jouissance, the schizophrenic dissolution of the boring old bourgeois ego ....' signals an interiorization of the concerns of an 'older transitional age', and of the work of the 'mošt creative and fascinating of the great class enemies, Edmund Burke' (p11). The equivalence Jameson suggests between Burke's concern with the Sublime and our more recent concern with the notion of jouissance is a useful one-alerting us to the possibility that embedded within much of the more recent theorizing of pleasure, there may lie traces of another somewhat reactionary and élitist discourse.

In his article 'A Poverty of Desire: Pleasure and Popular Politics', Colin Mercer argues that there is no unproblematic or straightforward strategy which might make possible 'the move from a text-bound conception of pleasure towards a political deployment of the term' (p87). Mercer argues that the history of the social construction and management of popular pleasures is also the history of the construction of the 'sovereign category' of the bourgeois individual. In order to hold all this together, what is needed, argues Mercer "is something analogous to the history of "discursive unities" that Foucault traces in his History Of Sexuality' (p98).

While Mercer is quite clearly dissatisfied with the now quite well established 'text-bound' and psychoanalytic approaches to the theorization of pleasure, the strength of his contribution is that he not only addresses himself to the contradictions within our present theories-he also suggests an alternative approach which might prove useful for feminist research.

Earlier on in the same article, Colin Mercer suggests that 'the agreement of politics and cultural analysis with pleasure does not only challenge the complicity of popular forms. It also dissolves the certainties and authority of the theorists' (p85). However, from my reading of the rest of this collection, I would suggest that this is by no means always the case. While Grahame Thompson and Tony Bennett both produce some interesting comments on Blackpool and the pleasures of the funfair, both their contributions seem to me to suffer from the authors having chosen pleasures which are not their own. This characterizes much of the work which has been produced as part of the 'pleasure boom'. Why is there, for instance, nothing in this collection on the pleasures of academia? And when Terry Eagleton does choose to look at his own pleasure in reading one line of a Yeats poem, why does the resulting essay read like a tongue in cheek exercise in self mockery?

This uneven collection, and the academic rush into 'pleasure' of which it forms a part, raise a number of questions. For while the promise of work on pleasure was that it might enable us to understand a little better the processes involved in cultural exchange, much of the work being produced seems to fall into the traps of élitism, obscurity, or just plain 'trendiness'. So why is work on pleasure and desire so popular at the moment? It is tempting to suggest that while feminist interventions in the field continue to disrupt and subvert commonsense notions of identity and sexuality, work being produced 
from within the more established, or patriarchal academic strongholds can be seen as an attempt to contain and incorporate the potentially disruptive power of this new field. I do not however think that this is a sufficient explanation for the production of such an uneven and prolific body of work. Could it be that in 1980s Thatcherite Britain, academics are seeking solace from the hard realities of daily life by burying themselves in 'pleasure'?

It is clear that in the present climate, anything with 'desire' or 'pleasure' in the title, will, like Mills and Boon Romances, sell and sell, yet in most people's daily lives there is undoubtedly a real lack of pleasure. While there is clearly a need to continue our attempts to understand the relation between pleasure, subjectivity and cultural exchange, isn't there also time to acknowledge the shared doubts and despairs which are prompting us to read and produce such an uneven mass of words about pleasure?

\section{Susannah Radstone}

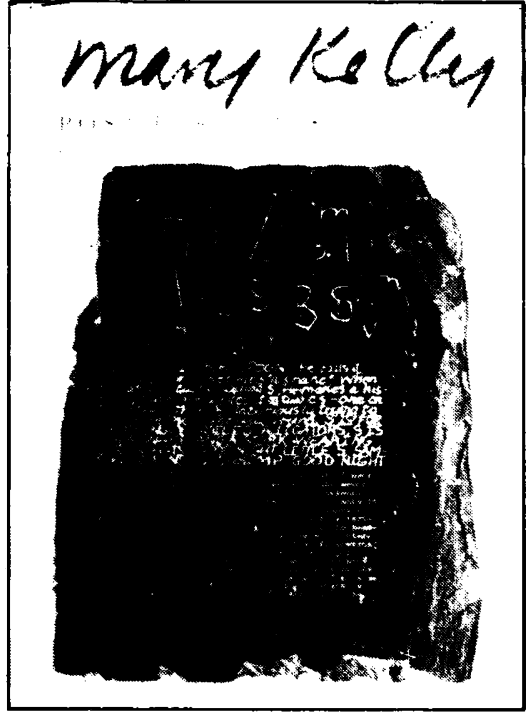

\section{Post-Partum Document Mary Kelly}

Routledge \& Kegan Paul 1983 212pp Hb $£ 14.95$ ISBN 0710094957

The Post-Partum Document (PPD) was conceived as an artwork, and exhibited widely throughout the late $1970 \mathrm{~s}$. It consists of six documents produced over a period of five years. Several of these have now been bought by various Arts Councils around the world, thereby restricting the likelihood of it being shown as a whole again. It thus seems appropriate for Mary Kelly to have revised her earlier opinion and reproduced the complete installation in book form together with its accompanying text. The book also includes an introduction by the American art critic Lucy Lippard and a reprinted selection of review articles which consider the work both from the perspective of feminism, and from that of modernist art practice.

Mary Kelly originally thought of the PPD as an attempt to document the experience of childbirth and childcare, to show the dominance of the mother-child relationship in both socialization and the formation of the unconscious. This concentration on experience in itself marked a break with traditional representations of mother and child stemming from madonna and child imagery. However, the final realization of the PPD broached an even more taboo subject: the construction of the mother's femininity through her fantasy life. The development of the PPD from 1973 to 1978 closely paralleled debates in feminist theory, which developed from concerns associated with the personal experience of consciousness-raising groups to more general questions concerning the social production of the subjective unconscious and the theorization of 'sexed subjectivity'.

To summarize briefly, in Mary Kelly's words, the PPD attempted:

to show the reciprocity of the process of socialization in the first few years of life. It is not 